DOI 10.32370/IA_2019_01_12

\title{
Historical and Pedagogical Aspects of National Education of Youth: Folklore Studies of Ukrainian Song
}

\author{
Komarovska Oksana \\ ORCID https://orcid.org/0000-0002-3679-9673 \\ Doctor of Sciences in Pedagogy \\ Head of Aesthetic and Art Education Laboratory of the Institute of \\ Problems on Education of the National Academy of Educational Sciences of Ukraine
}

\author{
Krus Oksana \\ ORCID https://orcid.org/0000-0002-9746-5554 \\ Rivne State University of Humanities, Ukraine, Senior Lecturer
}

\begin{abstract}
The article is devoted to the problem of national education of youth in Ukraine. The orientation of national education is the formation of national consciousness and national identity. The concept of national education has been defined as an integral personal quality that is dynamically enriched and its structure includes intercultural tolerance.

Particularly, the formation personality's intercultural tolerance is associated with a vector of interest in Ukrainian art and Ukraine in general by foreign cultural representatives. It is a significant factor in awakening of youth's pride for own artistic achievements, self-esteem and national identity.

The leading means of national education is Ukrainian folk art. The foreign studies on the Ukrainian folk song have been analyzed. A brief review of the works of outstanding foreign composers who used Ukrainian melody in their works (A. Dvozhak, L. Beethoven, F.List, B. Bartko) has been presented.

Key words: national education, national consciousness, intercultural connections, Ukrainian folk song, cover version of West European composers.
\end{abstract}

Актуальність проблеми. Важливою тезою, що об'єднує дослідження різних аспектів національного виховання, є теза про те, що воно спрямовано на формування національної свідомості і зумовлюється життям конкретної спільноти (етносу), своєрідністю історичного шляху, нею пройденого. За М. Боришевським, національна свідомість постає як «усвідомлення особистістю себе часткою певної національної (етнічної) спільноти та оцінку себе як носія національних (етнічних) цінностей, що склалися в процесі тривалого історичного розвитку національної спільноти, їі самореалізації як суб’єкта соціальної дійсності» [1, с. 138]. 
Ю. Римаренко, автор праць 3 теорії етносу, міжетнічних відносин та етнонаціональної політики, розглядає національне виховання і як ефективний засіб подолання у нашому суспільстві етностереотипів - комплексу меншовартості, вторинності і як «цілеспрямований, регульований процес утвердження національної самосвідомості, національних почуттів, національних традицій, національного характеру та національних особливостей психології, самоцінностей національноспецифічного (особливого), мовних, естетичних, етичних та інших цінностей народів, усього, що сприяє всебічному становленню національного» [14, с. 128].

Визнано, що найпотужнішим чинником національного виховання є мистецтво, передусім фольклорні мистецькі традиції, серед яких центральне місце посіла народнопісенна творчість. Поряд з цим, надзвичайно ефективним може стати осягнення ставлення іноземних авторів і митців до українського фольклору, передусім у вихованні почуття гордості за власні надбання в контексті світової спадщини.

Об'єктом дослідження у статті є українська народнопісенна творчість, непересічні цінності якої органічно вписалися в світову духовну спадщину і належать до унікальних за своїм значенням надбань національних культур; предмет - історія нотації та обробки української пісні авторами - чужинцями.

Мета статті - подати огляд фольклористичних досліджень зарубіжних учених, присвячених українській пісні, а також актуалізувати інтерес до неї у творах зарубіжних композиторів для використання в контексті національного виховання молоді.

Аналіз досліджень та виклад основного матеріалу. Проблема національного виховання, яка завжди хвилювала суспільство, відображена в численних дослідженнях видатних учених та педагогів-практиків (I. Бех, М. Боришевський, Ю. Бромлей, Г. Ващенко, І. Дзюба, В. Жмир, К. Журба, П. Кендзьор, О. Куць, С. Лавриненко, І. Огієнко, Л. Петько, Ю. Римаренко, Ю. Руденко, С. Русова, Р. Сойчук, Г. Філіпчук). Питаннями музичного фольклору як засобу національного виховання переймалися видатні митці - А.Авдієвський, В. Верховинець, С. Воробкевич, А. Іваницький, П. Козицький, О. Кошиць, М. Леонтович, М. Лисенко та інші. Важливими у цьому контексті є наукові фольклористичні розвідки, які висвітлюють історію вивчення української народної пісні і сам пісенний матеріал (О. Бенч, С. Горбенко, М. Гордійчук, 
С. Грица, Р. Осипець та ін.). Крім того, саме в напрямі національного виховання підростаючого покоління зростає інтерес до відображення фактів звернення зарубіжних митців різних поколінь до українського мистецтва та історії $[9 ; 12 ; 21 ; 22]$, що сприяє міжкультурному діалогу, невід’ємному від національної свідомості.

Історіографічну основу статті становлять видання, присвячені історії української пісні і пісенної поезії, біографічні дослідження творчості видатних зарубіжних композиторів, що зверталися до української пісні, народознавчі праці, публікації у засобах масової інформації, що стосуються цієї проблеми.

Як стверджують учені - фольклористи, чи не першим до студій української народнопісенної творчості звернувся чеський учений Я. М. Благослав. Це він у рукописній граматиці 1571 р. умістив українську народну пісню «Дунаю, Дунаю, чому смутен течеш?» [7, с. 18]. У 1625 р. в польській транскрипції було видано пісню про козака і Кулину. Німецький філософ і фольклорист Й.-Г. Гердер (1774-1803) особливо підкреслював природжені музичні здібності українців, багатство мотивів та образів українського народного мелосу. Готуючи збірник «Голоси народів у піснях» (1778-1779), який побачив світ німецькою мовою, вчений включив до нього й українські пісні [16].

Польський фольклорист Вацлав Залеський (1799-1849, псевдонім Вацлав 3 Олеська) видав у Львові збірник «Пісні польські і руські люду галицького» (1833), в якому подав майже 600 українських пісень. Інший польський учений - Жегота Паулі (1814-1895), подарував читачам двотомний збірник «Пісні руського народу в Галичині». (1839, 1840), вмістивши в ньому також чимало пісень із збірника М.Максимовича «Малороссийские песни», показавши, таким чином, спільну основу народнопісенної творчості, записаної на теренах Австрії і царської Росії. Як перекладач українських народних пісень німецькою мовою і пропагандист буковинського мелосу відомий Ю. Федькович. Серед перекладених ним фольклорних зразків - пісні про кохання, козацькі, рекрутські, жовнірські, народні балади тощо. Ю. Федькович ознайомив німецьких читачів із таким оригінальним жанром української народнопісенної творчості, як коломийки. На думку Ю. Федьковича, українська пісня не поступається своїм багатством жодній з інших слов'янських поезій, і навіть численні фольклорні збірники не можуть охопити всього їі розмаїття [18. с. 246, 249]. 
Справді, народна пісня стала візитівкою вітчизняної культури, символом іiі національної неповторності. Крім фольклористів, великий інтерес до нашого мелосу виявили композитори світового рівня, використовуючи його у своїй творчості. Скажімо, шлягер XVIII - початку XIX ст. «Їхав козак за Дунай» Семена Климковського - пісня, що, підкоривши більшість європейських країн, зафіксована і як шотландська народна пісня. Більше того, її обробку для різних ументів зробив Людвіг ван Бетховен. Відомо, що в Японії і зараз надзвичайно популярним є романс «Взяв би я бандуру» [15, c. 115].

Живий інтерес до українського фольклору спостерігається в XIX ст. серед західноєвропейських композиторів. Цікавий факт: молодший син Моцарта - Франц Ксавер у пошуках роботи опинився у Галичині - тоді околиці Австрійської імперії. Як відомо, після перебування певний час у родині Баворських біля Рогатина він учителював у сім’і камергера графа Янішевського в Сараках поблизу Бурштина, у родинах Потоцьких, Чарторийських і Сапег, а з 1813 року мешкав у Львові (тоді Лемберг). Тут Моцарт-молодший написав дві сонати, кілька пісень і фортепіанних п’єс за мотивами українських народних пісень, кантату й терцет [10]. Інтерес до української мелодики позначився й на фортепіанних варіаціях на тему української народної пісні «У сусіда хата біла», а також у «Думці на руську тему».

Україна й українська тема стали окремою сторінкою і в біографії Ференца Ліста (1811-1886). У 1847 році композитор місяць «проводить у стінах гостинного Києва» [4, с. 260], концертує в багатьох містах України ( ). В Україні він зустрів своє кохання. Натхненний враженнями, Ференц Ліст написав фортепіанні п’єси «Українська балада», «Думка» на теми українських народних пісень «Ой, не ходи, Грицю» і «Віють вітри, віють буйні», популярні й досі на Волинському Поліссі [3; 5].

Український фольклор вивчав ще один угорський композитор - Бела Барток (1881-1945). У 1888-1899 рр. він жив у місті Ці землі в той час перебували під владою Австро-Угорської імперії. 3 містом Севлюш (нині Виноградів) пов’язані для Бартока початок навчання гри на фортепіано, його перший музичний твір, перші публічні виступи. Пізніше Барток здійснив великий концертний тур містами України (Львів, Одеса, Харків та ін.). Серед його фольклорних обробок понад 80 українських пісень, а 
одна з частин його «Малої сюїти» для фортепіано має назву «Українська пісня»; також відомо про його активні творчі зв’язки з українськими митцями [13].

На сторінках газети «Радянська Україна» 27 серпня 1970 р. з’явилася замітка «Музичному роду нема переводу»: «С на Запоріжжі село Новгородівка. Здавна славиться воно музичними традиціями. А початок їм, як вважають старожили, поклала тутешня сім'я Дворжаків - нащадків видатного чеського композитора Антоніна Дворжака» [11]. Насправді, класик чеської музики А. Дворжак звертався не лише до чеського фольклору, а й здійснив обробки українських пісень «Ой у полі вишня» та «Ой кряче, кряче та й чорненький ворон». У музиці Дворжака кінця 1870-х - поч. 1890x pp. набув поширення жанр думки: фортепіанне тріо «Думки», п’єси «Думка» та «Думка й Фуріант»; думками Дворжак назвав повільні частини струнного квартету (ор. 51) і фортепіанного квінтету (ор. 81), думок для фортепіано [17]. Зазначимо, що ця цікава сторінка творчості великого чеського композитора класика ще потребує детальнішого вивчення.

Пригадаємо ім'я ще одного великого шанувальника нашого мелосу, а саме геніального польського композитора Фредерика Францишка Шопена. Так, видатний польський письменник i музичний критик Я. Івашкевич у повісті, присвяченій життєвому і творчому шляху Ф. Шопена, зазначав, що «близькі стосунки з родиною Кольбергів, його розмови про багатство нашої народної пісні спонукали молодшого за нього на чотири роки Оскара Кольберга (в майбутньому видатний етнограф, фольклорист, композитор, зібрав багатий, цінний фольклорно-етнографічний матеріал на терені Польщі та України; його основні праці (38 томів) стосуються народної музики, танців, звичаїв, обрядів. - О. Крусь) звернути увагу на зникаючі скарби. Якщо не вплив Шопена, то принаймні їхні розмови про це в надзвичайно цікавому середовищі Кольбергів могли викликати в обох юнаків оту їхню велику любов до національного фольклору» [6, с. 23]. Як відзначає Я. Івашкевич, Шопен добре знався не тільки на справжній українській пісні, а й на так званій «українській салонщині», яку музикознавці знаходять у творах Шопена. Вона за тих часів свідчила про природний контакт поляків з українською піснею, українською думкою і українським танцем безпосередньо через окраїнне земляцтво [2].

Висновок: Отже, у точнюючи національну вихованість особистості як іiі 
інтегральну якість, в якій національна самосвідомість постає як особистісне усталене утворення, що динамічно розвивається і збагачується, характеризується їі емоційним переживанням своєї національної належності, ціннісним ставленням до здобутків культури своєї нації й визнанням іiї багатогранності, повагою і толерантністю у ставленні до здобутків інших етносів та іï представників і зумовлює відповідні цим характеристикам вчинки i поведінку особистості в культурному просторі [8], підкреслимо: саме українська народна пісня є важливим чинником такого виховання; а усвідомлення іiі значення у формуванні міжкультурних зв’язків, міжетнічної толерантності, поваги до власної спадщини і спадщини інших культур має супроводжуватись пізнанням ставлення до українського з боку інших цих інших культур, що потребує вивчення фактів та їхньої систематизації і введення у педагогічну площину.

\section{References}

1. Boryshevskyi M.I. Natsionalna samosvidomist ta identyfikatsiia hromadian yak chynnyk demokratychnykh peretvoren $v$ ukrainskomu suspilstvi [National identity and identification of citizens as a factor in democratic transformations in Ukrainian society]. In Sotsialno-psykholohichnyi vymir demokratychnykh peretvoren v Ukraini. Kyiv: Ukrainskyi tsentr politychnoho menedzhmentu, 2003. P. 138-144.

2. Volska L. U poshukakh zviazkiv velykoho poliaka Federika Shopena z Ukrainoiu [In search of the connections between the great Polish Frederik Chopin and Ukraine]. Hazeta Den. 2010, December 24.

3. Volskaia L. List $v$ Ukraine: khronologiia $i$ geografiia [List in Ukraine: Chronology and geography]. Shapovalova L. V. (Ed). Problemy vzaiemodii mystetstva, pedahohiky ta teorii i praktyky osvity: zb. nauk. prats: Vol. 24. Kharkiv: Vydavnytstvo «TMT», 2009. P. 187-196.

4. Haal D. Sh. List [List]. Moscow: Pravda, 1986. 416 p.

5. Zinkevych O.S. Ferents List u Kyievi [Franz Liszt in Kyiv].Ukrainska muzychna spadshchyna: statti, materialy, dokumenty. Kyiv, 1989. Vol. 1. P. 53-66.

6. Ivashkevych Ya. Shopen [Chopin]. Kyiv: Muzychna Ukraina, 1989. 2008 p.

7. Istoriia ukrainskoi literatury (pershi desiatyrichchia XIX stolittia) [The history of Ukrainian literature (the first decades of the XIX century)]. Kyiv, 1992. $511 \mathrm{p}$.

8. Komarovska O.A. Khudozhni tsinnosti suchasnykh ditei: osoblyvosti proiavu ta diahnostuvannia [Artistic values of modern children: Features of manifestation and diagnosis]. Pedahohika i psykholohiia. Visnyk NAPN Ukrainy. 2017. Vol. 4(97). P. 57-62.

9. Komarovska O.A. Khudozhno-intonatsiinyi prostir zhyttia yak dzherelo tsinnostei pidrostaiuchoi osobystosti [Artistic and intonation space of life as a source of values of a growing personality]. Topical issues of education: Collective monograph. Pegasus Publishing, Lisbon, Portugal, 2018. P. 260-280.

10. Kostetska M. Utini velykoho batka [In the shadow of a great father]. Istoriia. 2017. No. 7 (44). P. 13. 
11. Muzychnomu rodu nema perevodu [Music genre has no end]. Radianska Ukraina. 1970. August 27.

12. Pet'ko L.V. Shlyahy formuvannya inshomovnoyi sociokulturnoyi kompetenciyi studentiv mystecz'kyh specialnostej VNZ u procesi fahovoyi pidgotovky. [The Ways of formation of foreign language socio-cultural competence of students of music-pedagogical specialties in high school in the process of professional teaching]. Problems of preparation of modern teacher. Uman' : PP Zhovtyj O. O., 2012. No 6. Part 3. Ch. 3 P. 57-62.

13. Pryndiuk O. Zvuky Uhorshchyny: U stolytsi hratymut tvory Bely Bartoka, dytynstvo yakoho proishlo na Zakarpatti [Sounds of Hungary: Bela Bartok's works, whose childhood was played in Transcarpathia, will play in the capital]. Ukraina moloda. 2015. October 21.

14. RymarenkoYu.I. Natsionalnyi rozvii Ukrainy: problem i perspektyvy [National development of Ukraine: Problems and prospects]. Kyiv: Yurinkom Inter, 1995. $272 \mathrm{p}$. 2001. $184 \mathrm{p}$.

15. Saukh P.Iu. XX stolittia. Pidsumky [The XX century. Results]. Kyiv Rivne,

16. Sichynskyi V. Chuzhyntsi pro Ukrainu [Strangers about Ukraine]. Lviv: VydvoSvit, $1991.94 \mathrm{p}$.

17. Siuta B. Dvorzhak Antonin. Entsyklopediia suchasnoi Ukrainy [Dvorak Antonin. Encyclopedia of modern Ukraine]. URL: http://esu.com.ua/search_articles.php?id=23782

18. Ukrainske narodoznavstvo, stan i perspektyvy rozvytku nazlami vikiv: Zb. nauk. prats [Ukrainian ethnography, state and prospects of development at the turn of the century]. Kyiv, 2002. $634 \mathrm{p}$.

19. Komarovska O. Art Pedagogics in the Context of Civilizational Change: On the Problems of Teacher Training / Professional Artistic Education and Culture within Modern Global Transformations; ed. by O. Oleksiuk. Cambridge: Cambridge Scholars Publishing. 2018. PP. 79-85.

20. Komarovska Oksana, Xia Gaoyang. Polyartistic potential of Music theory subjects in training Music teachers. Intellectual Archive. - Toronto: Shiny World Corp. (Canada). 2018. (November/December). Vol. 7. No. 6. PP. 82-89. https://doi.org/10.32370/2018_11_10

21. Pet'ko Lyudmila. Priorities for the development of the Ukrainian national idea and the upbringing students of this modern era. Intellectual Archive. Toronto: Shiny World Corp. (Canada). 2017. September/October. Vol. 6. No. 5. PP. 59-78.

22. Pet'ko Lyudmila. Sociocultural comprehension of ethnoconcept "RED RUE" // Science and society: Collection of scientific articles. - Edizioni Magi, Roma, Italia, 2017. P. 460-466.

\section{Translation of the Title, Abstract and References to the Author's Language}

УДК 37.035.6:784.4

Комаровська О., Крусь О. Історико-педагогічний аспект національного виховання молоді: фольклористичні дослідження української пісні.

Стаття присвячена проблемі національного виховання молоді в Україні. Орієнтиром національного виховання розглядається формування національної свідомості. Формулюється поняття національної вихованості як інтегральної 
особистісної якості, до структури якої, зокрема, внесено міжкультурну толератнтість. Міжкультурна толерантність пов'язується 3 вектором інтересу до українського мистецтва та України загалом з боку іноземних представників культури. Провідним засобом національного виховання розглядається українська народнопісенна творчість. Проаналізовано погляди зарубіжних авторів на українську народну пісню, творчість зарубіжних композиторів, які використовували український мелос у своїх творах.

Ключові слова: національне виховання, національна свідомість, міжкультурні зв'язки, українська народна пісня, обробки західноєвропейських композиторів.

\section{Лimepamypa}

1. Боришевський М.Й. Національна самосвідомість та ідентифікація громадян як чинник демократичних перетворень в українському суспільстві / Соціальнопсихологічний вимір демократичних перетворень в Україні. Київ: Український центр політичного менеджменту, 2003. С. 138-144,

2. Вольська Л. У пошуках зв'язків великого поляка Федеріка Шопена 3 Україною. День. 2010, 24 грудня.

3. Вольская Людмила. Лист в Украине: хронология и география. Проблеми взаємодіі мистецтвва, педагогіки та теорії $і$ практики освіти: зб. наук. праць. / [Редактор та упорядник - Шаповалова Л. В.]. Харків: Видавництво «НТМТ», 2009. Вип. 24. С. 187-196.

4. Гаал Д.Ш. Лист. Москва: Правда, 1986. 416 с.

5. Зінкевич О.С. Ференц Ліст у Києві. Українська музична спадщина : статті, матеріали, документи. Київ, 1989. Вип. 1. С. 53-66.

6. Івашкевич Я. Шопен ; пер. $з$ пол. Й. Й. Брояка. Київ: Музична Україна, 1989. $2008 \mathrm{c}$. $1992.511 \mathrm{c}$

7. Історія української літератури (перші десятиріччя XIX століття). Київ,

8. Комаровська О.А. Художні цінності сучасних дітей: особливості прояву та діагностування. Педагогіка $і$ психологія. Вісник НАПН України. 2017. № 4(97). С. 57-62.

9. Комаровська О.А. Художньо-інтонаційний простір життя як джерело цінностей підростаючої особистості // Topical issues of education: Collective monograph. - Pegasus Publishing, Lisbon, Portugal, 2018. P. 260-280.

10. Костецька Марія. У тіні великого батька. Історія. 2017. № 7 (44). С. 13: іл.

11. Музичному роду нема переводу. - Радянська Україна. 1970. 27 серпня.

12. Петько Л. В. Шляхи формування іншомовної соціокультурної компетенції студентів мистецьких спеціальностей ВНЗ у процесі фахової підготовки. Проблеми підготовки сучасного вчителя : зб. наук. праць Уманського державного педагогічного університету імені Павла Тичини / [ред. кол. : Побірченко Н. С. (гол. ред.) та ін.]. Умань : ПП Жовтий О. О., 2012. - Вип. 6. - Ч. 3. - С. 57-62.

13. Приндюк Ольга. Звуки Угорщини: У столиці гратимуть твори Бели Бартока, дитинство якого пройшло на Закарпатті. Україна молода. 2015. 21 жовтня.

14. Римаренко Ю.І. Національний розвій України: проблеми і перспективи : монография. Київ: Юрінком Інтер, 1995. 272 с.

15. Саух П.Ю. ХХ століття. Підсумки. Київ- Рівне, 2001. 184 с.

16. Січинський В. Чужинці про Україну. Львів: Вид-во Світ, 1991. 94 с. 
17. Сюта Б. Дворжак Антонін / Енциклопедія сучасної України. URL: http://esu.com.ua/search_articles.php?id=23782

18. Українське народознавство, стан і перспективи розвитку на зламі віків: зб. наук. праць. Київ, 2002. 634 с.

19. Komarovska O. Art Pedagogics in the Context of Civilizational Change: On the Problems of Teacher Training / Professional Artistic Education and Culture within Modern Global Transformations ; ed. by O.Oleksiuk. Cambridge: Cambridge Scholars Publishing. 2018. PP. 79-85.

20. Komarovska Oksana, Xia Gaoyang. Polyartistic potential of Music theory subjects in training Music teachers. Intellectual Archive. - Toronto: Shiny World Corp. (Canada). 2018. (November/December). Vol. 7. No. 6. PP. 82-89.

URL: https://doi.org/10.32370/2018_11_10

21. Pet'ko Lyudmila. Priorities for the development of the Ukrainian national idea and the upbringing students of this modern era. Intellectual Archive. Toronto: Shiny World Corp. (Canada). 2017. - September/October. Vol. 6. No. 5. PP. 59-78.

22. Pet'ko Lyudmila. Sociocultural comprehension of ethnoconcept "RED RUE" // Science and society: Collection of scientific articles. - Edizioni Magi, Roma, Italia, 2017. P. 460-466. 